\title{
Densidade mineral óssea de idosas independentes com diferentes perfis físico-funcionais e polimorfismos do gene do receptor da vitamina $D$
}

\author{
Myriam Fernanda Merli ${ }^{1}$ \\ Regina Célia Poli Fredico \\ Emily Delalibera Ruzzon \\ Rubens Alexandre da Silva Junior \\ Karen de Barros Parron Fernandes \\ Denilson de Castro Teixeira ${ }^{1,3}$ \\ Audrey de Souza Marquez \\ Vanessa Suziane Probst²
}

\begin{abstract}
The aim of the study was to compare BMD among physically independent elderly women with different physical-functional profiles and vitamin $\mathrm{D}$ receptor gene (VDR) polymorphisms, as well as to analyze the effect of the interaction between these last two aspects on BMD. Overall, 165 elderly women had BMD assessed by bone densitometry. Handgrip and lower limb strength and functional exercise capacity (6MWT) were also assessed. VDR polymorphisms (TaqI, BsmI, ApaI and FokI) were analyzed by polymerase chain reaction. For analyses, elderly women were categorized according to their performance on physical-functional tests into low performance (LP; $<25$ th percentile), normal performance (NP; 25 th percentile $\leq \mathrm{NP} \leq 75$ thpercentile) and high performance (HP; 75 th percentile). Regarding functional exercise capacity, LP group showed lower $\mathrm{BMD}$ compared to HP and NP groups $(\mathrm{p}=0,003)$. With respect to handgrip strength, there was a trend for LP group to have lower bone mineral density compared to NP group $(p=0.08)$. No differences were observed in femur and lumbar BMD in comparisons among the different VDR genotypes $(0.07 \leq \mathrm{p} \leq 0.94)$; among different groups regarding lower limb strength $(p=0.49)$ and in the interaction analysis among variables $(0.17 \leq p \leq 0.77)$. It was concluded that physically independent elderly women with low functional exercise capacity have lower bone mineral density than those classified as normal and high performance. However, apparently, there is no effect of the interaction between VDR gene polymorphisms and physical and functional factors on BMD.
\end{abstract}

Key words: Elderly; Bone density; Exercise tolerance; Genetics.

Resumo - O objetivo do estudo foi comparar a DMO entre idosas fisicamente independentes com diferentes perfis físico-funcionais e polimorfismos do gene do receptor da vitamina $D(V D R)$, assim como analisar a interação entre estes dois últimos aspectos sobre a DMO. Participaram do estudo 165 idosas, as quais tiveram a DMO avaliada por meio da densitometria óssea. Foram avaliadas também a força de preensão manual (FPM), força de membros inferiores (FMI) e a capacidade funcional de exercicio (TC6min). Os polimorfismos do gene VDR (TaqI, BsmI, ApaI e FokI) foram analisados pela reação em cadeia da polimerase. Para as análises, as idosas foram categorizadas de acordo com seu desempenho físico-funcional em baixo desempenho (BD; <percentil 25), desempenho normal ( DN; percentil $25 \leq D N \leq$ percentil 75 ) e alto desempenho (AD; > percentil 75). Para a capacidade funcional de exercício, o grupo BD apresentou menor $D M O$ em comparação ao grupo $A D$ e $D N(p=0,003)$. Em relação à $F P M$, o grupo $B D$ apresentou uma tendência a menor DMO quando comparado ao grupo DN ( $p=0,08)$. Não foram observadas diferenças na DMO do fêmur e da lombar na comparação entre os genótipos do gene $\operatorname{VDR}(0,07 \leq p \leq 0,94)$; entre os grupos em relação à $F M I(p=0,24)$ e na análise de interação entre as variáveis $(0,17 \leq p \leq 0,77)$. Pode-se concluir que as idosas fisicamente independentes com baixa capacidade funcional de exercicio apresentam menor DMO que aquelas com desempenho normal e alto desempenho. No entanto, aparentemente não existe interação entre os polimorfismos do gene VDR e o desempenho físico-funcional sobre a DMO.

Palavras-chave: Densidade óssea; Genética; Idosos; Tolerância ao exercício.
1 University of Northern Parana. Research Center on Health Sciences. Londrina, PR, Brazil.

2 State University of Londrina. Laboratory of Research in Respiratory Physiotherapy. Physiotherapy Department. Londrina, PR. Brazil.

3 State University of Londrina. Centre for Physical Education. Department of Physical Education. Londrina, PR. Brazil.

Received: 28 February 2015 Accepted: 02 November 2015 


\section{INTRODUCTION}

Increasing age is associated with profound changes in the health status of individuals, such as sarcopenia and decreased bone mineral density (BMD) 1. With regard to BMD, literature has shown that genetic factors account for approximately 60 to $80 \%$ of interindividual variability. In this sense, genetic research has grown, especially in relation to vitamin $\mathrm{D}$ receptor gene $(V D R)$. It is noteworthy that vitamin $\mathrm{D}$ along with its receptor is one of the most important components of bone metabolism; hence $V D R$ gene is one of the most important genes studied in this research field ${ }^{2}$.

The pioneering study by Morrison et al. ${ }^{3}$ demonstrated that recessive genotype of the $V D R$ gene was associated with higher BMD. Houston et al. ${ }^{4}$ have found association between recessive genotype and lower BMD. In contrast, other studies have shown that genetics was not related to $\mathrm{BMD}^{5,6}$.

It is known that in addition to $V D R$ gene polymorphisms, BMD is influenced by environmental factors and the interaction of both ${ }^{7}$. In this context, physical and functional factors can be highlighted as important contributors of BMD. Some studies ${ }^{8-10}$ have investigated the relationship between physical performance and BMD and found modest associations between variables. Zimmernan et al. ${ }^{9}$ and Foley et al. ${ }^{10}$ showed no correlation between handgrip strength and BMD. Thus, how physical performance in physical and functional tests is related to BMD is still unclear in literature.

Regarding the interaction between $V D R$ gene polymorphism and physical and functional performance, studies have shown that the dominant effect is associated with increased BMD in physically active women ${ }^{7,13}$. Moreover, Tsuritani et al. ${ }^{11}$ found that the recessive allele is more responsive to physical exercise. Jarvinen et al. ${ }^{12}$ found no interaction between genetics and physical activity, demonstrating that the bone tissue benefited from physical activity regardless of VDR gene.

Importantly, to date, the six-minute walk test, which assesses the functional exercise capacity, widely covered by the world literature, has not been used in studies analyzing the physical and functional factors related to BMD. Thus, the $6 \mathrm{MWT}$ deserves to be better investigated as it is a simple and inexpensive test ${ }^{13}$. In addition, its functional feature may reflect the potential to perform activities of the daily living ${ }^{13}$, which makes the results of the $6 \mathrm{MWT}$ and possible links with BMD highly relevant.

Thus, considering that there are still gaps with respect to the effect of the interaction between $V D R$ gene polymorphisms and physical and functional tests on BMD, the aim of this study was to compare the BMD among physically independent elderly women with different physical and functional profiles and $V D R$ gene polymorphisms and to analyze the effect of the interaction between these last two aspects on BMD.

\section{METHODS}

\section{Study design and subjects}

A cross sectional study was carried out from September 2009 to January 2013. 
The convenience sample consisted of elderly women of an interdisciplinary project (EELO Project; Study on Aging and Longevity) developed at the University of Northern Parana (UNOPAR) that aimed to evaluate sociodemographic factors and indicators of the health conditions of this population in Londrina, Paraná, Brazil. Further information is available at http:// www2. unopar.br/sites/eelo page. The EELO project had a total sample of 508 older adults, which is representative of the total population of 43,610 older adults in Londrina. This population of Londrina represents $12 \%$ of the total population, which is similar to what has been described in other countries ${ }^{14}$.

Later, from the database of the EELO project, the sample was selected for the performance of bone density examination. The selection criteria for performing bone densitometry were being physically independent and / or active according to functional status classification of Spirduso (levels 3 and 4, respectively) ${ }^{15}$. According to Spirduso, elderly classified as Level 3 are able to develop light physical work, but are sedentary and have low functional reserve. Those classified as Level 4 perform regular physical activity and functional capacity are above average; have performed three physical and functional tests (handgrip strength, sitting and standing test and six-minute walk test) and do not make use of drugs that interfere in bone metabolism. Of the 323 individuals who met the inclusion criteria, 42 were not found, 28 refused to participate and nine died. Thus, 244 elderly individuals performed bone densitometry examination. For the analysis of this study, however, only women were considered $(n=165)$. This study was approved by the Ethics Research Committee of UNOPAR (PP0070 / 09) and all participants signed the free informed consent form.

\section{Anthropometric data}

Initially, individuals were evaluated for body mass and height with an anthropometric scale (Filizola ${ }^{\circledR}$, São Paulo, Brazil), and then the body mass index (BMI) was calculated using the formula (body mass. height ${ }^{-2}$ ). The protocol used was that of Guedes \& Guedes ${ }^{16}$.

\section{Ethnic evaluation}

Ethnic evaluation was performed by the same team of students and teachers, in this case the appraiser, to define the racial group that the individual belongs according to skin color.

\section{Diagnosis of Osteoporosis}

Bone mineral density was assessed by the dual-energy densitometer unit (QDR 4500, Hologic Inc., Bedford, USA) in the regions of the lumbar spine (L1-L4) and femoral neck. The interpretation for diagnosis was performed according to WHO criteria: normal BMD with T-score of up to $-1.0 \mathrm{SD}$, osteopenia $\mathrm{T}$-score ranging from -1.0 to $-2.4 \mathrm{SD}$ and osteoporosis $\mathrm{T}$-score $\leq-25 \mathrm{SD}$ at any bone site. The bone mineral density values in the lumbar spine (L1-L4) were also analyzed in g. $\mathrm{cm}^{2}$. Examinations were performed in a private clinic in the city of Londrina, Paraná. 
For the analysis of BMD in g.cm², 46 elderly women were excluded from the sample, since according to the T-score, they showed worse diagnosis in the femur region (region where the values in $\mathrm{g} . \mathrm{cm}^{2}$ are not obtained). Thus, 119 participants were considered in these analyses.

\section{Collection of material for DNA analysis}

DNA was obtained from peripheral blood leukocytes collected with EDTA using PureLink Genomic DNA extraction kit (Invitrogen, Carlsbad, USA). The extracted DNA was stored in a freezer at $-80^{\circ} \mathrm{C}$ until time of analysis of polymorphisms.

Evaluation of the DNA quality and quantity was performed by analysis of absorbance in a spectrophotometer (NanoDrop 2000 - Thermo Scientific) at $260 \mathrm{~nm}$ and $280 \mathrm{~nm}$. Subsequently, DNA dilution was performed in ultrapure Milli- ${ }^{\circledR}$ water to final concentration of $30 \mathrm{ng} / \mathrm{uL}$.

\section{Polymerase chain reaction (PCR) and analysis of vitamin D receptor gene (VDR) polymorphisms}

For the analysis of single nucleotide polymorphisms (SNPs) of the $V D R$ gene, amplification technique was performed of DNA fragments by polymerase chain reaction (PCR) in real time by TaqMan ${ }^{\circledR}$ system (Applied Biosystems, Foster City, USA). Four polymorphisms were observed: TaqI (rs731236), BsmI (rs1544410), Apal (rs7975235) and FokI (rs2228570). The standard reaction used contained $20 \mu \mathrm{L}$ final volume as follows: $10 \mu \mathrm{l}$ of Taqman ${ }^{\circledR}$ Genotyping Master Mix (1x), 0.5 $\mu$ L probe (1x) (Applied Biosystems, Foster City, USA) $7.5 \mu \mathrm{L}$ ultrapure Milli- ${ }^{\circledR}$ water and $2 \mu \mathrm{L}$ DNA (30ng / uL). Thermocycler StepOnePlus ${ }^{\text {TM }}$ Real-Time PCR System (Applied Biosystems, Foster City, USA) was used with the following cycling: $60^{\circ} \mathrm{C}$ for 30 seconds (pre denaturation), $95^{\circ} \mathrm{C}$ for 10 minutes for initial denaturation, 50 cycles of $95^{\circ} \mathrm{C}$ for 15 seconds (denaturation) and $60^{\circ} \mathrm{C}$ for 1 minute and 30 seconds (pairing of primers) and final extension cycle of 30 seconds at $60^{\circ} \mathrm{C}$. The evaluation of results was performed by the StepOne Software v2.3.

\section{Handgrip strength}

Handgrip strength (HGS) was evaluated by manual dynamometer (Takei, Kiki, Kogyo, Japan), according to protocol proposed by Vianna et al. ${ }^{17}$.

Individuals remained standing with arm outstretched and dynamometer next to the body ${ }^{17}$. Two maximum handgrip strength measurements in both upper limbs were alternately performed, with an interval of 30 seconds, and the best result was chosen for analysis ${ }^{17}$.

\section{Lower limb strength}

Lower limb strength (LLS) was evaluated using the sitting and standing test. This test consists of sitting and standing from a chair without support, with arms folded across the chest the fastest as possible for 30 seconds $^{18}$. The test was performed only once after familiarization and the number of complete repetitions was recorded. 


\section{Functional exercise capacity}

Functional exercise capacity was assessed using the six-minute walk test (6MWT), according to protocol of the American Thoracic Society (ATS) ${ }^{13}$. Two tests were performed in a hallway of thirty meters with minimum interval of thirty minutes, and the highest value was used for analysis. The reference values of Britto et al. ${ }^{19}$ were used.

\section{Categorization of physical and functional tests}

Older women were categorized according to their performance in physical and functional tests as low performance (LP) (below the $25^{\text {th }}$ percentile), normal performance (NP) (within $25-75^{\text {th }}$ percentile) and high performance (HP) (above $75^{\text {th }}$ percentile), based on the study by Rikli \& Jones ${ }^{20}$.

\section{Statistical analysis}

Data distribution was analyzed using the Shapiro-Wilk test. Considering the normality of the data, parametric or non-parametric tests were applied. For comparison of bone mineral density (T-score and / or g. $\mathrm{cm}^{2}$ ) among groups with different performance in physical and functional tests, oneway ANOVA and Kruskal-Wallis tests were used with Tukey and Dunn post-tests, respectively. The interaction analysis was performed using the two-way ANOVA test and Bonferroni post-test. The chi-square test was used to compare categorical variables. Correlations were evaluated using the Pearson and Spearman correlation coefficient.

For the study of genetic variables, the chi-square test was used to analyze the Hardy-Weinberg equilibrium. The level of statistical significance adopted for all analyses was $\mathrm{p}<0.05$.

The sample power was calculated using the GPower ${ }^{\circledR} 3.1$ software. Correlation between BMD and functional exercise capacity (6MWT) was used, alpha 0.05 , correlation for null hypothesis of 0 , sample size of 119 , resulting in sample power of 0.80 .

The statistical programs used for analyses were GraphPadPrism 5.0 (GraphPad Software Inc., San Diego, USA), Statistical Package of Social Science (SPSS) 20.0 (SPSS Inc., Chicago, USA), Statistica (StatSoft Inc., Tulsa, USA).

\section{RESULTS}

The sample consisted of 165 physically independent elderly women. In relation to bone mineral density, most had osteopenia ( $\mathrm{n}=92 ; 56 \%), 52$ participants (31\%) had osteoporosis and 21 (13\%) had normal BMD. The general sample characteristics are presented in Table 1.

\section{BMD and functional exercise capacity, handgrip strength and lower limb strength \\ With regard to functional exercise capacity, LP group had lower BMD of the lumbar spine $\left(\mathrm{g} . \mathrm{cm}^{2}\right)$ compared to HP and NP groups $(\mathrm{p}=0.003)$}


Table 1. General sample characteristics

\begin{tabular}{lccccc}
\hline & General & $\begin{array}{c}\text { Normal BMD } \\
(\mathrm{n}=21)\end{array}$ & $\begin{array}{c}\text { Osteopenia } \\
(\mathrm{n}=92)\end{array}$ & $\begin{array}{c}\text { Osteoporosis } \\
(\mathrm{n}=52)\end{array}$ & $\mathrm{p}$ \\
\hline Age (years) & $68 \pm 5.6$ & $67 \pm 5$ & $67 \pm 5.2$ & $69 \pm 6.3$ & 0.06 \\
BMI (Kg/m²) & $28 \pm 4.6$ & $30 \pm 4.5^{*}$ & $29 \pm 4.2^{*}$ & $25 \pm 4.3$ & $0.0001^{*}$ \\
6MWT (\% prev.) & $102 \pm 11.4$ & $105 \pm 9.8^{*}$ & $103 \pm 11.1$ & $98 \pm 12$ & $0.022^{*}$ \\
LLS (No. repetitions) & $11 \pm 2.2$ & $11 \pm 2.3$ & $12 \pm 2.1$ & $11 \pm 2.2$ & 0.47 \\
HGS (Kg/f) & $24 \pm 4.6$ & $25 \pm 3.2$ & $24 \pm 4.7$ & $23 \pm 4.7$ & 0.06 \\
Ethnicity (n) (W/B/B/Y) & $(99 / 29 / 29 / 8)$ & $(9 / 9 / 3 / 0)$ & $(62 / 9 / 16 / 5)$ & $(28 / 11 / 10 / 3)$ & 0.58 \\
\hline
\end{tabular}

Data are expressed as mean (standard deviation); absolute frequency; Normal BMD (T-score >-1.0 SD); Osteopenia: T-score between -1.01 and -2.49 SD; Osteoporosis: T-score $\leq-2.5$ SD; BMI: Body Mass Index; 6MWT: Six-minute walk test; \% prev .: percentage of the predicted value; LLS: Lower Limb Strength; No: number of correct repetitions; HGS: Handgrip Strength; Kg / f: kg / force; n: number of individuals; W: white; B: Black; B: brown; Y: yellow. ${ }^{*} p<0.05$ vs osteoporosis. $n=165$.

(Figure 1). Correlation was observed between lumbar spine BMD $\left(\mathrm{g} \cdot \mathrm{cm}^{2}\right)$ and percentage of the predicted value in the $6 \mathrm{MWT}(\mathrm{r}=0.22 ; \mathrm{p}=0.02)$.

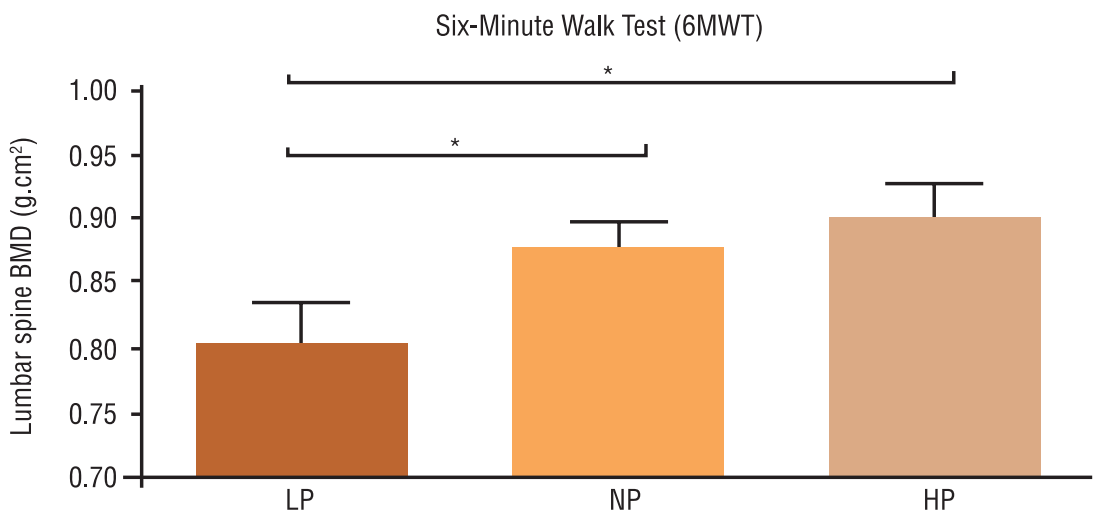

Figure 1. Comparison of lumbar spine BMD among elderly women with different performance on the Six-Minute walk test (6MWT). LP: Low Performance; NP: Normal Performance; HP: High Performance. $n=119$. ${ }^{\star} p=0.003$.

Comparing the lumbar spine BMD (g. $\left.\mathrm{cm}^{2}\right)$ among groups with different performance in the HGS test, LP group showed tendency to lower BMD when compared to NP group ( $\mathrm{p}=0.08$ ) (Figure 2). In addition, no correlation was found between lumbar spine BMD (g.cm²) and HGS (r $=0.09 ; \mathrm{p}=0.32$ ). Regarding LLS, there was no significant difference in $\mathrm{BMD}$ in the comparison among groups $(\mathrm{p}=0.24)$ (Figure 3 ) and there was no correlation between BMD and LLS ( $r=0.12 ; \mathrm{p}=0.22)$. Correlations between BMD of the lumbar spine $\left(\mathrm{g} . \mathrm{cm}^{2}\right)$ and age $(\mathrm{r}=-0.24 ; \mathrm{p}=0.01)$, body mass $(r=0.47 ; p=0.0001)$ and BMI $(r=0.47 ; p=0.0001)$ were found.

\section{Comparison of BMD among VDR gene polymorphisms}

In relation to bone mineral density (BMD) in the different genotypes (dominant, recessive and heterozygous) of $V D R$ gene polymorphisms (TaqI, $B s m I, A p a I$ and FokI), there was no significant difference in the specific site comparisons to the bone site of the lumbar spine and femoral neck, as shown in Table 2 . 


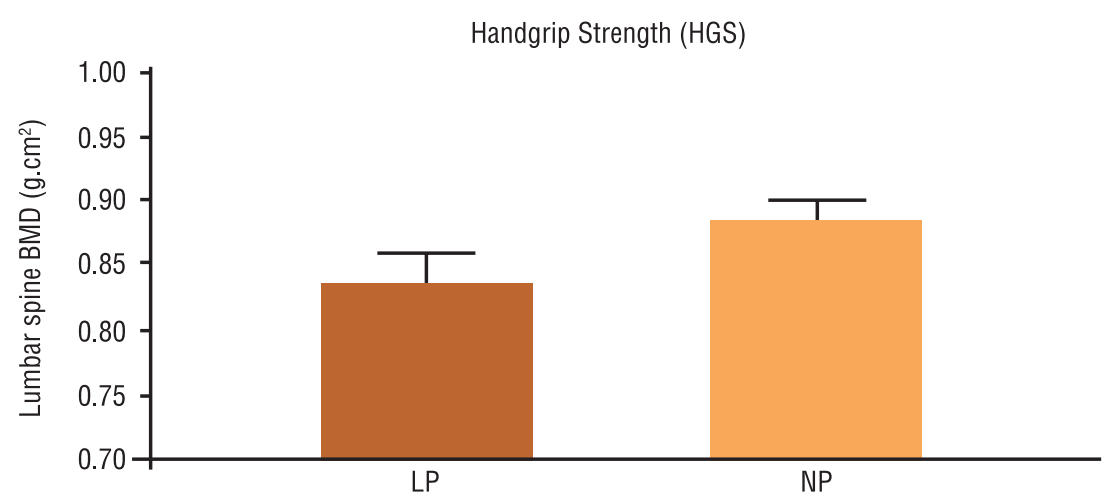

Figure 2. Comparison of lumbar spine BMD among elderly women with different performance in handgrip strength (HGS). LP: Low Performance; NP: Normal Performance. $n=119 . p=0.08$.

Lower Limb Strength (LLS)

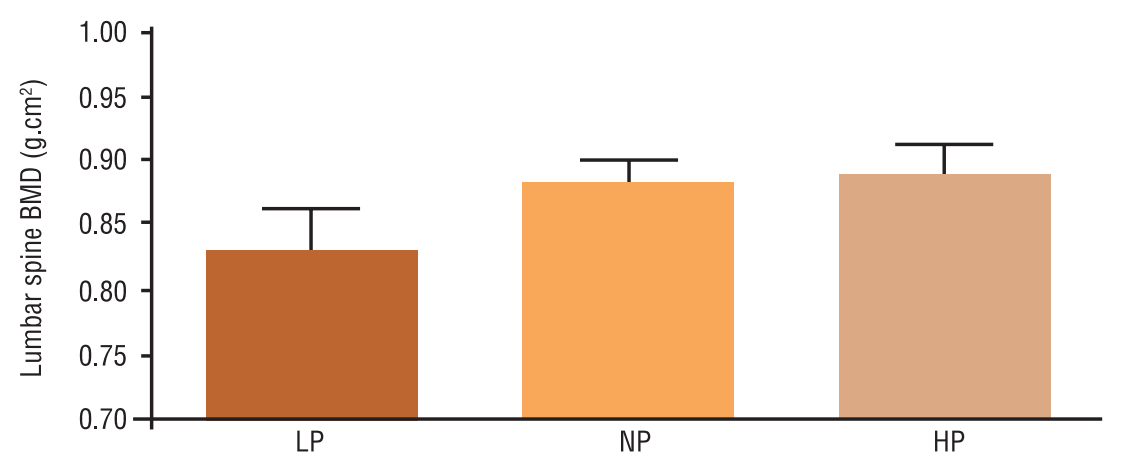

Figure 3. Comparison of lumbar spine BMD among elderly women with different performance on lower limb strength (LLS). LP: Low Performance; NP: Normal Performance; HP: High Performance. $N=119 p=0.24$.

Table 2. Comparison of bone mineral density (BMD) in different vitamin D receptor gene (VDR) polymorphisms

\begin{tabular}{|c|c|c|c|c|c|c|c|c|c|c|c|c|c|c|c|c|c|}
\hline & & \multicolumn{16}{|c|}{ VDR gene polymorphisms } \\
\hline & & \multicolumn{4}{|c|}{ Taql } & \multicolumn{4}{|c|}{ Bsml } & \multicolumn{4}{|c|}{ Apal } & \multicolumn{4}{|c|}{ Fokl } \\
\hline & & TT & tt & $\mathrm{Tt}$ & $p$ & BB & $\mathrm{bb}$ & $\mathrm{Bb}$ & $p$ & $A A$ & aа & $\mathrm{Aa}$ & $p$ & $\mathrm{FF}$ & $\mathrm{ff}$ & $\mathrm{Ff}$ & $p$ \\
\hline Sampl & $e(n)$ & 63 & 23 & 79 & - & 60 & 2 & 103 & - & 71 & 18 & 76 & - & 24 & 73 & 68 & - \\
\hline \multirow{2}{*}{ 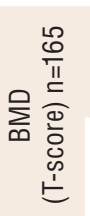 } & $\vec{\Phi}$ & $\begin{array}{c}-1.32 \\
\pm 1.49\end{array}$ & $\begin{array}{c}-1.40 \\
\pm 1.19\end{array}$ & $\begin{array}{c}-1.74 \pm \\
1.40\end{array}$ & 0.31 & $\begin{array}{c}-1.43 \\
\pm 1.41\end{array}$ & $\begin{array}{c}-1.35 \\
\pm 0.21\end{array}$ & $\begin{array}{c}-1.60 \\
\pm 1.43\end{array}$ & 0.94 & $\begin{array}{c}-1.45 \\
\pm 1.29\end{array}$ & $\begin{array}{c}-1.06 \\
\pm 1.20\end{array}$ & $\begin{array}{c}-1.72 \\
\pm 1.55\end{array}$ & 0.16 & $\begin{array}{c}-1.98 \\
\pm 1.79\end{array}$ & $\begin{array}{c}-1.54 \\
\pm 1.49\end{array}$ & $\begin{array}{l}-1.37 \\
\pm 1.15\end{array}$ & 0,16 \\
\hline & 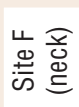 & $\begin{array}{c}-1.70 \pm \\
1.16\end{array}$ & $\begin{array}{c}-1.47 \\
\pm 0.73\end{array}$ & $\begin{array}{r}-1.89 \\
\pm 0.99\end{array}$ & 0.16 & $\begin{array}{c}-1.76 \pm \\
1.10\end{array}$ & $\begin{array}{c}-2.05 \\
\pm 0.35\end{array}$ & $\begin{array}{c}-1.76 \pm \\
1.01\end{array}$ & 0.57 & $\begin{array}{c}-1.60 \\
\pm 0.91\end{array}$ & $\begin{array}{c}-1.76 \pm \\
1.14\end{array}$ & $\begin{array}{l}-1.91 \\
\pm 1.11\end{array}$ & 0.07 & $\begin{array}{r}-1.90 \\
\pm 1.01\end{array}$ & $\begin{array}{l}-1.77 \\
\pm 1.17\end{array}$ & $\begin{array}{c}-1.69 \\
\pm 0.88\end{array}$ & 0,46 \\
\hline \multicolumn{2}{|c|}{ Sample (n) } & 44 & 17 & 58 & - & 41 & 2 & 76 & - & 51 & 12 & 56 & - & 19 & 52 & 48 & - \\
\hline \multicolumn{2}{|c|}{$\begin{array}{l}\text { BMD Site L } \\
\left(\mathrm{g} \cdot \mathrm{cm}^{2}\right) \\
\mathrm{n}=119\end{array}$} & $\begin{array}{c}0.883 \\
\pm \\
0.14\end{array}$ & $\begin{array}{c}0.899 \\
\pm \\
0.15\end{array}$ & $\begin{array}{c}0.843 \\
\pm \\
0.14\end{array}$ & 0.35 & $\begin{array}{c}0.871 \\
\pm \\
0.13\end{array}$ & $\begin{array}{c}0.961 \\
\pm \\
0.11\end{array}$ & $\begin{array}{c}0.860 \\
\pm \\
0.15\end{array}$ & 0.54 & $\begin{array}{c}0.878 \\
\pm \\
0.13\end{array}$ & $\begin{array}{c}0.954 \\
\pm \\
0.18\end{array}$ & $\begin{array}{c}0.834 \\
\pm \\
0.14\end{array}$ & 0.09 & $\begin{array}{c}0.821 \\
\pm \\
0.17\end{array}$ & $\begin{array}{c}0.850 \\
\pm \\
0.17\end{array}$ & $\begin{array}{c}0.899 \\
\pm \\
0.13\end{array}$ & 0.17 \\
\hline
\end{tabular}

Data are expressed as mean and standard deviation; absolute frequency; $n$ : number of individuals; Site L: lumbar spine bone mineral density; Site F (lap): femoral neck BMD; Normal BMD (T-score>-1.0 SD); Osteopenia: T-score between -1.01 and -2.49 SD; 0steoporosis: T-score $\leq-2.5$ SD; : Kruskal Wallis test value. $n=165$ for classification according to the T-score; $n=119$ for lumbar spine BMD in $\mathrm{g} . \mathrm{cm}^{2}$.

\section{Effect of the interaction among genetic, physical and functional factors on BMD}

There was no effect of the interaction between genetic polymorphisms (TaqI, BsmI, ApaI and FokI) of the VDR gene and functional exercise capacity (6MWT) on BMD ( $\mathrm{p}=0.58)$, as well as with other physical and 
functional tests (handgrip strength and sitting and standing test) $(\mathrm{p}=0.77$; $p=0.17$, respectively).

\section{DISCUSSION}

This study showed that physically independent elderly women with low functional exercise capacity had lower lumbar spine BMD compared to elderly women with normal performance and high performance. In addition, BMD correlated with functional exercise capacity and anthropometric factors in this population. However, there was no difference in BMD in relation to $V D R$ gene polymorphisms (TaqI, BsmI, ApaI and FokI) and there was no effect of the interaction between $V D R$ gene polymorphisms and physical and functional tests on BMD.

With regard to the association between BMD and exercise capacity, Taaffe et al. ${ }^{8}$ showed that white men with poor aerobic capacity assessed by 400-meter walking test were 2.78 times more likely to have osteoporosis. Although the methodology used by Taaffe et al. ${ }^{8}$ is different from that of the present study, results were similar, that is, poor physical performance is associated with lower BMD. It is noteworthy that the present study showed for the first time association between 6MWT (test widely used in the evaluation of functional exercise capacity in healthy subjects and patients with chronic diseases) and BMD.

In relation to lower BMD in elderly women with low functional physical performance, studies have shown an association between handgrip strength and $\mathrm{BMD}^{21,22}$. It is known that the adjustment observed in bone mass to typical mechanical use demonstrates the mechanisms that control longitudinal growth, and bone modeling and remodeling directly determines bone mass, a mechanism known as Frost Theory ${ }^{23}$. This theory has been used to explain the association between physical activity and increased bone mineral content due to mechanical stress on the muscle contraction bone tissue. Indeed, elderly women with better physical and functional performance regarding handgrip strength were those more likely to have higher BMD values. It could be hypothesized that these individuals have more preserved muscle strength because they have higher levels of habitual physical activity, which could contribute to the preservation of BMD. However, the level of habitual physical activity unfortunately has not been evaluated in this study. Accordingly, other studies have shown relationship between peripheral muscle strength assessed by another test (sitting and standing test) and $\mathrm{BMD}^{8}$. In the present study, there was no difference in BMD among groups with different performance on the sitting and standing test. It could be inferred that this test evaluates the lower limb physical function, involving different aspects of performance, such as, lower limb muscle strength and balance. Thus, there is no way to isolate the muscle component, because as the evaluation is performed dynamically, balance interferes considerably in the outcome. Thus, the specific analysis between lower limb muscle streng th and BMD is compromised using the 
sitting and standing test. However, it is noteworthy that studies related to BMD and aging involve mostly large samples; thus, simpler methodologies end up by being used. Since this study involves a subsample of another population study, a test for the evaluation of muscle strength with simple methodology was used so that it could be applied to a large number of individuals without the need for expensive equipment of difficult mobility.

Other studies have shown no association between BMD and peripheral muscle strength ${ }^{9,10}$, as in the present study. In the study of Zimmernan et al. ${ }^{9}$, this may have occurred due to sample size (56 subjects), which may have been insufficient to identify the association, a factor that should also be considered in this research. Foley et $a 1 .{ }^{10}$ have reported that the lack of association between peripheral muscle strength and BMD is due to that fact that the muscles evaluated were not adjacent to the site where BMD was measured. However, literature shows that the simple handgrip strength measure may represent the peripheral muscle strength in a generalized way ${ }^{24}$. In addition, the great advantage of assessing handgrip strength is the evaluation method because it is simple, easy, noninvasive, and is important predictor of functionality, nutritional status and mortality in the elderly, which use is highly relevant in clinical practice ${ }^{24}$. Other studies used peripheral muscle strength tests such as the sitting and standing test also found no correlation with BMD. This is the case of the results of Lindsey et al..$^{22}$ and those of the present study. The lack of association between these variables may be related to the nature of this functional test ${ }^{18}$, with dynamic characteristics that involve other skills such as balance, coordination, agility, and may not reflect specifically the peripheral muscle strength, as previously mentioned.

Modest and positive correlation between anthropometric variables (body mass and body mass index) and BMD was observed. Kang et al. ${ }^{25}$ and Salamat et al. ${ }^{26}$ also found positive correlation between body mass and BMD in their studies. Regarding BMI, Salamat et al. ${ }^{26}$ found an association between BMD and body mass index, showing that lower BMI is associated with lower BMD. Higher body mass, whether in relation to lean or fat body mass, leads to greater mechanical stress due to the muscle work to support body or locomotion, which consequently results in stimulation for bone formation ${ }^{27}$, explaining the relationships between body mass, BMI and BMD.

It was identified that age is negatively correlated with BMD. This finding corroborates the findings of Kang et al. ${ }^{25}$ that advancing age is associated with lower BMD. It is known that age is a risk factor for low $\mathrm{BMD}$, because after the age of thirty years, BMD has a declining rate of one percent per year ${ }^{1}$. However, the correlation between age and BMD found in this study was weak $(r=-0.24 ; p=0.01)$. This finding can be explained by the sample size, the small age variability and the profile of individuals included, i.e., all were physically independent, showing no aspect of fragility that could directly influence BMD.

There were no differences in $\mathrm{BMD}$ in relation to $V D R$ genotypes. 
However, literature has demonstrated relationships between polymorphic variations of the $V D R$ gene and $\mathrm{BMD}^{3,4}$. Other studies ${ }^{5,6}$ found no association between $V D R$ gene polymorphisms (TaqI, ApaI, BsmI) and BMD, which corroborates our findings. It is important to highlight how TaqI, BsmI and ApaI polymorphisms affect the vitamin $\mathrm{D}$ receptor action, as they have no effect on the end product of the protein encoded by the $V D R$ gene, but modulate gene expression ${ }^{5}$. In the present study, it could be inferred that the effects of $V D R$ polymorphisms were discrete in relation to all factors affecting $B M D$, in addition to the sample size.

Regarding the association of $V D R$ gene polymorphisms and physical and functional tests and bone mineral density, this study found no interaction among such variables. Similarly, Jarvinen et al. ${ }^{12}$ also found no interaction between $V D R$ gene polymorphism and physical activity in pre menopausal women. The authors of that study showed that bone benefited from physical activity regardless of genotype. Moreover, Blanchet et al. ${ }^{28}$ and Gentil et al. ${ }^{7}$ showed that the dominant genotype is associated with increased BMD in physically active women. Tsuritani et al. ${ }^{11}$ found that the recessive genotype is more responsive to exercise. These contradictions show that more studies are needed to confirm the interaction between $V D R$ gene polymorphisms, physical and functional tests and BMD. In addition, in relation to polymorphisms, they should be evaluated not only in isolation, but using their combination through the haplotype study.

It should be also mentioned that in addition to physical and functional factors, other environmental components can also influence BMD. Among them, smoking, alcohol, low calcium intake, vitamin D insufficiency, estrogen deficiency, late menarche and low weight. These aspects, associated with genetics, make the study of the interaction between physical and functional performance and $V D R$ gene polymorphisms on BMD quite complex, given the numerous existing environmental factors ${ }^{29}$.

According to the authors, this is the first study investigating the interaction between $V D R$ gene polymorphisms, muscle strength and functional exercise capacity measured by objective methods. Until then, interaction studies described in literature were limited to the investigation of physical aspects through questionnaires. Furthermore, the main $V D R$ gene polymorphism (TaqI, ApaI, BsmI and FokI) were investigated, highlighting the methodological relevance of this study.

Regarding the study limitations, it could be said that the groups showed strong tendency of age differences, which may have contributed to accentuate the findings in the study variables. However, the age of all participants was not discrepant (66 [63-71] years), which can reduce the effect of aging on variables. In addition, the sample may not have been sufficient to detect interactions among variables. It is possible that, for more conclusive statements about the genetic profile, it was necessary to consider a larger number of individuals and the variants of the $V D R$ gene should be assessed using their combination by means of the haplotype study. Furthermore, the quantification of the protein levels of $V D R$ or even the 
transcript of this gene (mRNA) should be performed in order to confirm the bioactivity hypothesis of this protein: how $V D R$ gene polymorphisms could modulate the gene expression and the production of this receptor, which could explain why carriers of certain alleles would show lower BMD. The lack of assessment of physical activity in the daily life can be considered as another limitation, since it could add important information about the physical condition of these individuals.

With regard to the clinical application of the results of this study, the presence of association between functional exercise capacity testing and BMD shows that based on the physical performance assessment of older women, it is possible to identify individuals more likely to have osteopenia and osteoporosis. Thus, for subjects with lower BMD and hence increased risk of fracture, a more specific and early therapeutic approach should be recommended.

\section{CONCLUSIONS}

In short, physically independent elderly women with low functional exercise capacity have lower bone mineral density than those with normal and high performance. However, there is no apparent interaction between $V D R$ gene polymorphism and physical and functional performance on bone mineral density.

\section{REFERENCES}

1. Riggs BL, Wahner HW, Melton LJ 3rd, Richelson LS, Judd HL, Offord KP. Rates of bone loss in the appendicular and axial skeletons of women. Evidence of substantial vertebral bone loss before menopause. J Clin Invest 1986;77(5):1487-91.

2. Liu YZ, Liu YJ, Recker RR, Deng HW. Molecular studies of identification of genes for osteoporosis: the 2002 update. J Endocrinol 2003;177(2):147-96.

3. Morrison NA, Qi JC, Tokita A, Kelly PJ, Crofts L, Nguyen TV, et al. Prediction of bone density from vitamin D receptor alleles. Nature 1994;367(6460):284-7.

4. Houston LA, Grant SF, Reid DM, Ralston SH. Vitamin D receptor polymorphism, bone mineral density, and osteoporotic vertebral fracture: studies in a UK population. Bone 1996;18(3):249-52.

5. Horst-Sikorska W, Dytfeld J, Wawrzyniak A, Marcinkowska M, Michalak M, Franek E, et al. Vitamin D receptor gene polymorphisms, bone mineral density and fractures in postmenopausal women with osteoporosis. Mol Biol Rep 2013;40(1):383-90.

6. Zajickova K, Zofkova I, Bahbouh R, Krepelova A. Vitamin D receptor gene polymorphisms, bone mineral density and bone turnover: FokI genotype is related to postmenopausal bone mass. Physiol Res 2002;51(5):501-9.

7. Gentil P, de Lima Lins TC, Lima RM, de Abreu BS, Grattapaglia D, Bottaro M, et al. Vitamin-d-receptor genotypes and bone-mineral density in postmenopausal women: interaction with physical activity. J Aging Phys Act 2009;17(1):31-45.

8. Taaffe DR, Simonsick EM, Visser M, Volpato S, Nevitt MC, Cauley JA, et al. Lower extremity physical performance and hip bone mineral density in elderly black and white men and women: cross-sectional associations in the Health ABC Study. J Gerontol A Biol Sci Med Sci 2003;58(10):M934-42.

9. Zimmermann CL, Smidt GL, Brooks JS, Kinsey WJ, Eekhoff TL. Relationship of extremity muscle torque and bone mineral density in postmenopausal women. Phys Ther 1990;70(5):302-9. 
10. Foley KT, Owings TM, Pavol MJ, Grabiner MD. Maximum grip strength is not related to bone mineral density of the proximal femur in older adults. Calcif Tissue Int 1999;64(4):291-4.

11. Tsuritani I, Brooke-Wavell KS, Mastana SS, Jones PR, Hardman AE, Yamada Y. Does vitamin D receptor polymorphism influence the response of bone to brisk walking in postmenopausal women? Horm Res 1998;50(6):315-9.

12. Jarvinen TL, Jarvinen TA, Sievanen H, Heinonen A, Tanner M, Huang XH, et al. Vitamin D receptor alleles and bone's response to physical activity. Calcif Tissue Int 1998;62(5):413-7.

13. ATS Committee on Proficiency Standards for Clinical Pulmonary Function Laboratories. ATS statement: guidelines for the six-minute walk test. Am J Respir Crit Care Med 2002;166(1):111-7.

14. Lutz W, K CS. Dimensions of global population projections: what do we know about future population trends and structures? Philos Trans R Soc Lond B Biol Sci 2010;365(1554):2779-91.

15. Spirduso WW,dimensões físicas do envelhecimento. Barueri: Manole; 2005.

16. Guedes DP, Guedes JERP, manual prático para avaliação em educação física. Barueri - SP: Manole; 2006.

17. Vianna LC, Oliveira RB, Araujo CG. Age-related decline in handgrip strength differs according to gender. J Strength Cond Res 2007;21(4):1310-4.

18. Jones CJ, Rikli RE, Beam WC. A 30-s chair-stand test as a measure of lower body strength in community-residing older adults. Res QExerc Sport 1999;70(2):113-9.

19. Britto RR, Probst VS, de Andrade AF, Samora GA, Hernandes NA, Marinho PE, et al. Reference equations for the six-minute walk distance based on a Brazilian multicenter study. Braz J Phys Ther 2013;17(6):556-63.

20. Rikli RE, Jones CJ. Functional Fitness Normative Score for Community-Residing Older Adults, Ages 60-94. J Aging Phys Act 1999(7):162-81.

21. Kim SW, Lee HA, Cho EH. Low handgrip strength is associated with low bone mineral density and fragility fractures in postmenopausal healthy Korean women. J Korean Med Sci 2012;27(7):744-7.

22. Lindsey C, Brownbill RA, Bohannon RA, Ilich JZ. Association of physical performance measures with bone mineral density in postmenopausal women. Arch Phys Med Rehabil 2005;86(6):1102-7.

23. Frost HM. Bone "mass" and the "mechanostat": a proposal. Anat Rec 1987;219(1):1-9.

24. Bohannon RW. Dynamometer measurements of hand-grip strength predict multiple outcomes. Percept Mot Skills 2001;93(2):323-8.

25. Kang D, Liu Z, Wang Y, Zhang H, Feng X, Cao W, et al. Relationship of body composition with bone mineral density in northern Chinese men by body mass index levels. J Endocrinol Invest 2014;37(4):359-67.

26. Salamat MR, Salamat AH, Abedi I, Janghorbani M. Relationship between Weight, Body Mass Index, and Bone Mineral Density in Men Referred for Dual-Energy X-Ray Absorptiometry Scan in Isfahan, Iran. J Osteoporos 2013;2013:205963.

27. Reid IR, Ames R, Evans MC, Sharpe S, Gamble G, France JT, et al. Determinants of total body and regional bone mineral density in normal postmenopausal women-a key role for fat mass. J Clin Endocrinol Metab 1992;75(1):45-51.

28. Blanchet C, Giguere Y, Prud'homme D, Dumont M, Rousseau F, Dodin S. Association of physical activity and bone: influence of vitamin $\mathrm{D}$ receptor genotype. Med Sci Sports Exerc 2002;34(1):24-31.

29. Kung AWC, Huang Q-Y. Genetic and environmental determinants of osteoporosis. J Musculoskelet Neuronal Interact 2007;7(1):26-32.

\section{CORRESPONDING AUTHOR}

Vanessa Suziane Probst Laboratory of Research in Respiratory Physiotherapy (LFIP) Physiotherapy Department State University of Londrina (UEL) Av. Robert Koch, 60 - Vila Operária CEP 86038-350 - Londrina, PR, Brasil

Email:vanessaprobst@uol.com.br 